ISSN 2413-0877 Volume 2 (2015) 630

The 3rd International Conference on Biological Science 2013

(The 3rd ICBS-2013)

\title{
IDENTIFICATION OF BULBING HORMONE GENES IN ONION (Allium cepa)
}

\author{
Minami Tagashira and Tsuyoshi Kaneta \\ Graduate School of Science and Engineering, Ehime University \\ e-mail : uma_zura18@yahoo.co.jp
}

\begin{abstract}
Initiation of onion (Allium cepa L.) bulb formation seems to require "bulbing hormone" which has been considered to be produced in leaf blades in response to the stimulus of long day conditions. But "bulbing hormone" is not yet identified. Previous study revealed a protein called Flowering locusT (FT) as flowering hormone, florigen. FT act for flowering by change on the day length on the higher plants. Objective of this study is identify"bulbing hormone" in onion plants. Method used in this study are cloning gene and gene expression analysis of the FT in onion plants. Full length of cDNA was cloned by the degenerate PCR and 5'and 3'-RACE method.As a result, six kinds of full length cDNA clones for FThomologs in onion plants were obtained.These genes were named AcFT1 to6. By expression analysis of these genes, AcFT4, 5 and 6 ,expression increased as it got closer to a condition in long days in association with the bulbing of onion. Furthermore, in order to investigate the functions of these genes, we optimize transformation methods for onion plants. Medium containing 2,4-Dand kinetin showed high efficient plant regeneration from seed-derived callus of onion. Medium containing 2,4-D and kinetin as plant growth regulators is effective for induction of shoot-inducible callus, and advance shoots were developed from the callus on the shoot induction medium which contained thidiazuron, benzyl adenine or trans-zeatin as cytokinins. In conclusion, bulbing hormone in onion plants were possibly gene AcFT4, 5,6.
\end{abstract}

Key words : Allium cepa L, bulbing hormone gene, Flowering locus T

ISSN 2413-0877 @ 2015 The Authors.

Published by KnowledgeE Publishing Services This is an open access article under the CC BY-NC-ND license (http://creativecommons.org/licenses/by-nc-nd/4.0)

Selection and Peer-review under responsibility of the 3rd ICBS-2013

Doi http://dx.doi.org/10.18502/kls.v2i1.232 